Prace Historyczno-Archiwalne t. XXXII

ISSN: 1231-3335

\author{
Anna Kasiarz \\ ORCID 0000-0003-1182-8535 \\ DOI: 10.30657 /pha.32.2020.05 \\ (Uniwersytet Rzeszowski) \\ e-mail: anna.kasiarz@wp.pl
}

\title{
Zjazd w Dzikowie w 1927 roku
}

\section{Streszczenie}

Tarnowscy, jeden z najstarszych i najznaczniejszych rodów ziemiańskich II Rzeczypospolitej, doświadczyli w latach 1918-1939 zjawisk i przemian, jakie były udziałem całej ich sfery. Ostatni przedstawiciele rodu - Jan Zdzisław i jego syn Artur aktywnie uczestniczyli w życiu politycznym i społecznym, tak w wymiarze lokalnym, jak i ogólnopolskim. Pierwszy z nich był m.in. senatorem, drugi posłem w Parlamencie II RP. Obaj byli także liderami ruchu konserwatywnego, który przybierał w tamtym okresie różne formy organizacyjne. Apogeum znaczenia politycznego Tarnowskich był słynny zjazd konserwatystów małopolskich i ich spotkanie z wysłannikiem Piłsudskiego, płk. Walerym Sławkiem, w ich rodzinnym domu w 1927 roku. Tarnowscy, realizując swoistą misję, musieli z jednej strony osadzić ją w tradycji rodu i spuściźnie jego wielkich przedstawicieli, z drugiej zaś w zmieniających się dynamicznie procesach społecznych i politycznych lat trzydziestych XX wieku. Wierni testamentowi przodków i zasadom konserwatyzmu, stawali się coraz bardziej anachroniczni w świecie, w którym reguły wyznaczały totalitarne ideologie. II wojna światowa przyniosła zagładę dotychczasowego świata, a także kres polskiego ziemiaństwa.

\section{Słowa kluczowe:}

Tarnowscy, Dzików, II Rzeczpospolita, ziemianie, konserwatyzm

\footnotetext{
T endite in astra viri - dążcie do gwiazd mężowie - ta dewiza herbowa wpisała się $\mathrm{w}$ dzieje jednego $\mathrm{z}$ najsławniejszych rodów arystokratycznych Polski, Tarnowskich herbu Leliwa. Od XVI w. Tarnowscy związani byli z Dzikowem, gdzie aż do 1944 roku znajdowało się ich gniazdo rodzinne. Nie do przecenienia jest wkład Leliwitów Tarnowskich w historię i kulturę polską. Poczynając od działalności najsłynniejszego z nich, hetmana Jana Amora Tarnowskiego, a kończąc na ostatnim dziedzicu Dzikowa Arturze Tarnowskim.
} 
Prezentowany tekst koncentruje się przede wszystkim na fragmencie polityki wewnętrznej II Rzeczypospolitej, dotyczącym współpracy polskich konserwatystów, na czele których stał Zdzisław Tarnowski z Marszałkiem Józefem Piłsudskim.

Okres II Rzeczypospolitej charakteryzują ogromne zmiany społeczne i polityczne. Ziemianie, wraz z nimi Tarnowscy, musieli w tych zmienionych warunkach odnaleźć swoje miejsce. Co prawda, nadal stanowili grupę uprzywilejowaną w państwie, ale utrzymanie tej pozycji wymagało wzmożonej aktywności, umiejętności dopasowania się, a przede wszystkim zrozumienia, że arystokratyczne korzenie oraz majątek już nie wystarczą, aby odgrywać istotną rolę, nie tylko polityczną, ale też społeczną i gospodarczą. Po raz pierwszy w latach 1918-1926 warstwie ziemiańskiej przyszło żyć w państwie o ustroju republikańskim, w państwie, w którym nie odgrywała znaczącej roli politycznej. Sytuacja uległa zmianie w 1926 roku, kiedy na scenę polityczną wrócił Marszałek Piłsudski, oferując współpracę konserwatystom, których głównym zapleczem byli ziemianie. Dla nich układ quasi-monarchistyczny, stworzony przez Piłsudskiego, był nareszcie czymś znajomym, do czego można było się odnieść.

Wybór aktywności politycznej oraz służby krajowi wpisany był w dziedzictwo rodu Tarnowskich. Dlatego Zdzisław i Artur, panowie na Dzikowie, pomimo wewnętrznego oporu wobec stosowanych przez Marszałka sposobów przejęcia władzy w państwie, poparli majowy przewrót 1926 roku, licząc na ustabilizowanie wewnętrznej polityki w Polsce oraz uzyskanie przez konserwatystów wpływu na rządy.

W 1927 roku Dzików, rodowa siedziba Tarnowskich, stał się miejscem, do którego, dodajmy nie po raz pierwszy w jego dziejach, zawitała wielka historia. Dla wszystkich, którym znana była działalność hrabiego Zdzisława Tarnowskiego jako prezesa największego ugrupowania konserwatywnego, Stronnictwa Prawicy Narodowej, zjazd arystokracji polskiej nie był niczym nadzwyczajnym. Emocje jednak budził przyjazd nań przedstawicieli obozu rządowego. Co łączyło Józefa Piłsudskiego z konserwatystami? Dlaczego chciał ich pozyskać, wysyłając do Dzikowa najbliższych współpracowników? Jakie nadzieje wiązali polscy konserwatyści ze zmianami zaistaniałymi po przewrocie majowym 1926 roku? Czy udało się wykorzystać sprzyjającą koniunkturę, do jawnego, efektywnego działania politycznego? Próba odpowiedzi na te pytania pozwoli przybliżyć, często pomijany, ale jakże interesujący fragment historii Polski.

Aby zrozumieć polityczne zbliżenie Piłsudskiego i konserwatystów, należy sięgnąć do ich priorytetów. Czynnikami, które skłaniały obie strony do współpracy, były przede wszystkim: wspólny rodowód (podobnie jak większość konserwatystów, również Piłsudski pochodził z rodziny ziemiańskiej), niechęć do endecji, wzajemne docenianie potencjału intelektualnego oraz wspólna wizja przyszłości wschodnich rubieży Rzeczypospolitej, a także głoszone już odrodzonej Ojczyźnie hasła elitaryzmu i zmiany kształtu ustrojowego państwa. Oczywiście każdy z tych filarów zyskiwał w miarę upływu lat coraz szerszy zakres, ale też ulegał zmianom.

Biografowie Józefa Piłsudskiego często podkreślają, że dzieciństwo i młodość miały ogromny wpływ na osobowość i decyzje przyszłego Marszałka Polski. Ziemiańskie tradycje, kult Powstania Styczniowego, romantyczne usposobienie, a także poczucie misji wobec Ojczyzny i odpowiedzialności za swoje czyny przed potomnymi, były wyznacznikami polityki Piłsudskiego. 
Dodajmy do tego okres zesłania, który także znalazł odzwierciedlenie w sposobie uprawiania polityki, opartym na skrytości, tajemniczości, często samodzielności w podejmowaniu najważniejszych decyzji w państwie. Cechowała też Marszałka zadziwiająca umiejętność szybkiego oceniania możliwości swoich rozmówców, dzięki temu przez długi czas doskonale dobierał sobie współpracowaników, wręcz oddanych wykonawców swojej woli. Trzeba również zaznaczyć drzemiące - przez cały czas pełnienia funkcji niekwestionowanego przywódcy narodu polskiego - przekonanie, że wszystko, co czyni, czyni w imię dobra Polski. Prawica uważała go za socjalistę, lewicowcy za imperialistę, a konserwatyści przez długi czas obawiali się obu tych uproszczeń.

Niejednoznacznie w polskim społeczeństwie postrzegani byli również polscy konserwatyści, reprezentowani w dużej mierze przez potomków znakomitych rodów ziemiańskich. Dla jednych - obrońcy szańców starej magnaterii, starego porządku, nie nadążający za zmianami społecznymi, dla innych - strażnicy wolności, religii, wartości rodzinnych i honoru, a przede wszystkim szeroko rozumianej tradycji Polski. Widoczni na firmamencie politycznym od połowy wieku XIX, dopiero w 1907 roku stworzyli struktury organizacyjne m.in. w postaci Stronnictwa Prawicy Narodowej, na czele którego od poczatku stał hrabia Zdzisław Tarnowski. Okres II RP w działalności konserwatystów to nieustanne zmaganie się wierności idei konserwatywnej z realiami twardej „bezpardonowej” polityki, cechujacej odbudowę państwa polskiego. Niewidoczni w latach 1919-1927, często w zaciszu gabinetów, salonów, wykorzystując swoje wykształcenie, znajomość języków, koneksje międzynarodowe, wyrobienie polityczne z okresu zaborów, starali się uczestniczyć w budowaniu suwerennej państwowości.

Przed rokiem 1926 Józef Piłsudski intensywnie poszukiwał możliwości zbliżenia do konserwatystów, szczególnie do osób wpływowych w ich kręgach, czyniąc daleko idące obietnice, m.in. wstrzymania wykonania reformy rolnej czy ograniczenia ustawodawstwa socjalnego. Liczył, że konserwatyści odciągną od endecji znaczną część zwolenników, szczególnie zaś duchowieństwo oraz pomogą mu w prawnym kształtowaniu nowego ustroju państwa ${ }^{1}$.

Reakcja konserwatystów na przewrót majowy była różna: od potępienia na łamach „Czasu” po całkowite zrozumienie i popracie przez litewskich „Żubrów”. Jednak już pierwsze oświadczenia Piłsudskiego wydane po zamachu odpowiadały poglądom konserwatystów, dlatego też ich stosunek do przewrotu uległ ewolucji. Dość szybko zdecydowali się udzielić Marszałkowi poparcia.

20 lipca 1927 roku doszło do spotkania Józefa Piłsudskiego ze Zdzisławem Tarnowskim. Piłsudski wyraził chęć bliższej współpracy, proponując wspólne tworzenie programu ustrojowego sanacji. Zaproponował kilka własnych rozwiązań, które w znacznej mierze zgodne były z propozycjami konserwatystów (m.in. wzmocnienie władzy wykonawczej oraz ograniczenie roli parlamentu), podkreślił jednocześnie wartości, jakie konserwatyści mogą wnieść do polskiego życia politycznego. Efektem tego spotkania była wizyta Walerego Sławka w Dzikowie ${ }^{2}$. Warto szczegółowo prześledzić owo wydarzenie.

W dniach od 14 do 16 września 1927 roku w Dzikowie odbyła się konferencja grup konserwatywnych, reprezentowanych przez Stronnictwo Prawicy Narodowej, Stronnictwo Chrześcijańsko-Narodowe oraz Organizację Zachowawczej Pracy Pań-

1 W. T. Kulesza, Konserwatyści w obozie sanacyjnym w latach 1926-1935: spór o konserwatywnq interpretację ideologii obozu rzq̨dzq̨cego, „Przegląd Historyczny” 1982, nr 73/3-4, s. 229.

2 Ibidem, s. 230. 
stwowej, połączona ze spotkaniem z przedstawicielami Józefa Piłsudskiego. W Dzikowie hrabia Zdzisław Tarnowski powitał przybyłych:

z Warszawy:

hr. Wojciecha Roztworowskiego,

księcia Zdzisława Lubomirskiego,

Zygmunta Leszczyńskiego,

dr. Jana Bobrzyńskiego,

Józefa Targowskiego,

prezesa Adama Piaseckiego,

M. Rudzińskiego;

z Wielkopolski:

gen. Tadeusza Szułdrzyńskiego,

prof. hr. Adama Żółtowskiego,

prezesa Jana Lipskiego,

hr. Zygmunta Czarneckiego,

prof. Antoniego Chanowicza;

z Wileńszczyzny:

księcia Eustachego Sapiehę;

z Wołynia:

księcia Janusza Radziwiłła,

hr. Stanisława Czackiego;

z Krakowa:

prezesa Aleksandra Dworskiego,

hr. Rogera Raczyńskiego,

hr. Artura Potockiego,

barona Jana Goetz-Okocimskiego,

dr. Józefa Kadena,

prof. rektora Stanisława Estreichera,

dr. redaktora Antoniego Beaupre,

dr. Konstantego Grzybowskiego;

z Łodzi:

prezesa Robert Gayera;

ze Wschodniej Małopolski:

hr. Wojciecha Gołuchowskiego,

hr. Stanisława Badeniego,

Karola Bołoz-Antoniewicza,

prezesa Stanisława Komrowskiego,

hr. Juliusza Tarnowskiego,

prezesa Seweryna Dolańskiego;

w spotkaniu uczestniczyli równiez:

były poseł w Brukseli Józef Wielowieyski, ${ }^{3}$

prof. Alfred Ohanowicz,

hr. Artur Tarnowski,

dr. Aleksander Morawski.

3 Zjazd arystokracji w Dzikowie. Obecność adiutanta marszałka Piłsudskiego i referat ppł. Sławka, „Goniec Częstochowski” 1927, nr 216, s. 1. 
Ze strony rządu udział w spotkaniu wzięli:

płk Walery Sławek ${ }^{4}$

mjr hr. Remigiusz Grocholski. ${ }^{5}$

Należy zapytać, w jakim celu odbyło się to spotkanie? Odpowiedzi udzielił gospodarz zjazdu Zdzisław Tarnowski w swoim powitaniu. Zauważył, że konserwatyści, mając na uwadze dobro Polski, odsunięci jednak od wpływu na wydarzenia w państwie w dziedzinie ustrojowej i publicznej, chcą wykorzystać sprzyjającą aurę polityczną do otwartego, zgodnego z prawem działania. Istotnym elementem, od którego zależy skuteczne działanie, jest jego zdaniem zjednoczenie ruchu konserwatywnego. Ponadto hrabia wyraził zaniepokojenie faktem, że od roku mając otwarte do działania drzwi, w ruchu konserwatywnym tak naprawdę niewiele się dzieje ${ }^{6}$. Hr. Zdzisław Tarnowski potwierdził udział w spotkaniu przedstawicieli Józefa Piłsudskiego. Wzywał do prezentowania jednolitego stanowiska wobec obozu rządzącego. Podkreślił jednak towarzyski, prywatny charakter spotkania, zaznaczając, że od gości nie oczekuje się, by ich rozmowy i ustalenia przybrały konkretny kształt ustawy czy rozporządzenia, atmosfera spotkania powinna sprzyjać szczerości i otwartości $\mathrm{z}$ obu stron, tj. konserwatywnej i rządowej. Tym samym, twierdził, ułatwi to pozna-

4 Po zamachu majowym Walery Sławek został „oddelegowany” przez Piłsudskiego do realizacji jego planów względem polskich zachowawców. Kontrowersje historyków budzą intencje Marszałka dotyczące konserwatystów. Czy jego chęć współdziałania w tym okresie była szczera, czy chodziło tylko o współpracę doraźną? Wystąpienie Sławka w Dzikowie komentuje Miedziński w sposób następujący: Sławek nie zrozumiał intencji Marszałka, który dążył do taktycznego porozumienia z ruchem konserwatywnym, i związał się z ziemianami całkowicie szczerze, wręcz „wsiąkł w konserwatyzm, omal stawał się konserwatysta” [B. Miedziński, Ze wspomnień..., s. 146]. Sympatie Sławka były uzasadnione, bowiem wspólny katalog wartości, stosunek do tradycji, postrzeganie nadrzędności interesu państwa były wspólne dla niego i ruchu konserwatywnego. Zjazd w Dzikowie w 1927 roku otworzył nową kartę w działalności politycznej Sławka, a także konserwatystów. Dawała ona możliwość realizacji programu politycznego mającego na celu uzdrowienie stosunków w Polsce. W listopadzie 1927 roku stanął na czele BBWR, w latach 1930-1935 trzykrotnie pełnił funkcję premiera. Z pamiętników Janusza Jędrzejewicza wynika, że Piłsudski widział w nim przyszłego prezydenta Rzeczypospolitej. Ale zamiast zabiegać o prezydenturę, Walery Sławek zajął się wprowadzaniem w życie nowej ordynacji wyborczej i przygotowaniami do wyborów parlamentarnych. Co więcej, z relacji Jędrzejewicza wynika, że sam Sławek decyzją Piłsudskiego był głęboko zmartwiony, gdyż nie odpowiadał mu ten typ pracy i nie czułby się dobrze na tym stanowisku. [T. Chłopecki, Koncepcje elitaryzmu w myśli Walerego Sławka, „Prace z myśli polityczno-prawnej oraz prawa publicznego”, Wrocław 2012, s. 146]. Wśród piłsudczyków rosło grono zdecydowanych przeciwników Sławka, uważających go za niepoprawnego marzyciela. Po śmierci Piłsudskiego jego autorytet stopniowo malał. 30 października 1935 r. rozwiązał BBWR. Planował powołanie nowej organizacji pod nazwą Powszechnej Organizacji Społeczeństwa, ale skutecznie mu to uniemożliwiono. Przyglądał się z rozgoryczeniem działalności swoistego triumwiratu (prezydent Ignacy Mościcki, gen. Edward Rydz-Śmigły i minister spraw zagranicznych Józef Beck), który coraz śmielej odchodził od politycznego testamentu Piłsudskiego. Z perspektywy czasu można wysunąć wniosek, iż podobnie jak konserwatyści, Walery Sławek uważał, że istnieje granica ustępstw w polityce. Nie chciał polityki bez zasad; osamotniony, 2 kwietnia 1939 roku popełnił samobójstwo.

5 Protokół konferencji grup konserwatywnych z udziałem przedstawicieli marszałka Piłsudskiego w Dzikowie w dniach 14-16 września 1927 r., „Najnowsze Dzieje Polski” 1959, s. 201.

6 Ibidem, s. 204. 
nie kierunków polityki rządu7. Uprzedził, jakie pytania zada przybyłym, zachęcał tym samym do przygotowania się do dyskusji na następujące tematy: stosunku rządu do ugrupowań konserwatywnych w Polsce, stosunku do istniejących partii sejmowych, a także organizacji kampanii wyborczej i wizji przyszłego Sejmu ${ }^{8}$. Na zakończenie swego wystąpienia Tarnowski jeszcze raz podkreślił, że podstawowym założeniem, z którego powinni wychodzić zebrani konserwatyści, jest bezwzględnie pozytywny stosunek do Marszałka Piłsudskiego.

Po przedstawieniu planu zjazdu rozgorzała dyskusja, tematem wywołującym najwięcej kontrowersji było stanowisko wobec Narodowej Demokracji. Hr. Żółtowski zwrócił uwagę na trudne położenie $\mathrm{SChN}$, rozdartego między poparciem dla Piłsudskiego a poparciem dla Narodowej Demokracji. W pierwszym dniu narad jednak kwestia ta nie znalazła rozstrzygnięcia.

W dniu 15 września miało miejsce wyczekiwane wystąpienie Walerego Sławka. Swoista gra dyplomatyczna polegała na tym, że Sławek już w pierwszych słowach zaznaczył, iż nie reprezentuje na spotkaniu oficjalnego stanowiska rządu, a nawet stanowiska samego Piłsudskiego, gdyż ten zwykł nie zwierzać się ze swoich planów...9. Niemniej jednak dla wszystkich zgromadzonych było oczywistym, że wystąpienie konsultowano z Marszałkiem. Odpowiadając na pytania prezesa SPN Zdzisława Tarnowskiego, Walery Sławek sugerował, że w rządzie potrzebne jest ugrupowanie reprezentujące umiarkowane stanowisko polityczne. Konserwatyści polscy, twierdząc, że dobro jednostki wiąże się z dobrobytem państwa i tym samym nie można państwa traktować jak wroga, wpisują się w myśl obozu piłsudczyków. Istniejące partie polityczne, odsunięte od rządów w wyniku wydarzeń majowych 1926 roku, reprezentowały odmienne stanowisko, dbając przede wszystkim o własne interesy. Zdaniem Sławka, taka postawa wynikała z zaszłości historycznych: wrogi stosunek do państw zaborczych przeniesiono na państwo własne... ${ }^{10}$. Dlatego też, niewskazanym byłoby tworzenie nowych partii, które w miarę upływu czasu przekształciłyby się w ugrupowania mające na uwadze jedynie partykularne interesy. Przekaz tej wypowiedzi dla zgromadzonych zachowawców był oczywisty - Marszałek nie bierze pod uwagę utworzenia konserwatywnej partii politycznej. Przyszłą scenę polityczną miałyby kształtować nowe formy polityczne, będące pośrednikami między narodem a rządem. Powstałe kluby polityczne, grupujące ludzi o wysokim poziomie intelektualnym, moralnym i odwadze cywilnej, powinny nadawać ton życiu politycznemu Polski ${ }^{11}$. W sprawie relacji między rządem a Sejmem powinna wypowiedzieć się konstytucja. Sejm powinien dokonać reformy konstytucji, w duchu wzmocnienia władzy wykonawczej: Musi być w niej uwzględniony moment obrony interesów państwa przed anarchiq ze strony jednostki. Przekładnia musi zostać przerzucona z bankrutującego parlamentaryzmu na autorytet jednostki ${ }^{12}$.

Po opuszczeniu sali przez pułkownika, książę Sapieha dokonał podsumowania wystąpienia Walerego Sławka: konserwatyści są potrzebni, ale nie powinni organizować się w partię polityczną, ich zadaniem jest uczestnictwo w projekcie tworze-

\footnotetext{
Ibidem, s. 205.

8 Ibidem, s. 206.

9 Ibidem, s. 209.

10 Ibidem.

11 Ibidem, s. 210.

12 Ibidem.
} 
nia nowego typu ugrupowań w oparciu o reprezentantów interesów, wybory odbędą się w niezmienionej formie ${ }^{13}$, ponadto rząd oczekuje projektów nowej konstytucji. W późniejszej dyskusji stwierdzono, że przygotowanie projektu nowej konstytucji może stać się najlepszą platformą porozumienia między rządem a zachowawcami. Po odjeździe Sławka podsumowano osiągnięcia zjazdu w Dzikowie. Uzgodniono stanowisko konserwatystów wobec ND, wykluczając jakąkolwiek współpracę, postanowiono powołać do życia organ wykonawczy w celu prowadzenia rozmów z przedstawicielem rządu, w tym przypadku z Walerym Sławkiem, podjęto decyzję o opracowaniu rezolucji mającej na celu stworzenie wspólnego frontu konserwatywnego, na wniosek prezesa Piaseckiego postanowiono częściej organizować spotkania członków poszczególnych stronnictw konserwatywnych. Ostatecznie konserwatyści postanowili udzielić poparcia rządowi w przyszłych wyborach, chociaż nie byli jednomyślni, książę Sapieha stwierdził, że ...ogólny blok z sanacją nie jest możliwy, natomiast możliwe jest porozumienie lokalne. Hr. Żółtowski podkreślił, że trzeba wytłumaczyć płk. Sławkowi, że będziemy jednak tworzyć stronnictwo ${ }^{14}$.

Zjazd w Dzikowie wywołał różne komentarze w ówczesnej prasie, w zależności od jej zabarwienia politycznego. Głos prasy konserwatywnej, początkowo lakoniczny, w miarę odgłosów dobiegających zarówno z lewej, jak i z prawej strony sceny politycznej stawał się wyraźny. Początkowo „Czas” i „Dzień Polski” ograniczyły się jedynie do krótkiej notatki o tym, kiedy i kto przybył do Dzikowa. Jednak już 20 września 1927 roku na łamach „Dnia Polskiego” ukazał się obszerny, entuzjastyczny artykuł Jan Bobrzyńskiego. Autor zwracał uwagę, że konserwatystom nareszcie udało się pokonać przeszkody prowadzące do konsolidacji ruchu zachowawczego. Zjazd w Dzikowie, zdaniem Bobrzyńskiego, był nie tylko swoistym kamieniem węgielnym na drodze tej konsolidacji, ale także zapowiedzią zmian w ówczesnej polityce wewnętrznej państwa, charakteryzującej się sejmokractwem i partyjniactwem. [...] Obecnie zapełnić się ma wielka luka, ziejąca dotąd od chwili wskrzeszenia państwa polskiego na prawicy, zapełnić się ma żywiołem umiaru politycznego i twórczej myśli państwowej, wykutej z długoletniego doświadczenia. Na szalach polityki państwowej nastąić ma równowaga, której dotąd brakowało. A równowaga ta umożliwi... dzieło naprawy Rzeczypospolitej ${ }^{15}$. W dalszej części artykułu mówi o reformach ustrojowych państwa, które zakończą okres żerowania na państwie i targowania się z nim pod płaszczykiem patriotyzmu, gruntowna przemiana tych tendencji antypaństwowych na państwowe - twórcze, ofiarujące ojczyźnie wszystko bez targu - oto pierwszy i fundamentalny warunek naprawy Rzeczypospolitej ${ }^{16}$. Sugeruje również, iż zasklepianie się $\mathrm{w}$ wewnętrznych utarczkach stało się przyczyną lekceważenia i niedostrzegania sprzyjającej międzynarodowej koniunktury politycznej, a co za tym idzie, niewykorzystywania jej: postulaty Polski mocarstwowej, nie zaś doktryny lub hasła klasowe i partyjne, dyktować nam powinny... podstawowe wytyczne reform ustrojowych i organizacji gospodarczej, tak aby naród i państwo mogły sprostać $w$ odpowiednich momentach swym zadaniom ${ }^{17}$.

13 Ibidem

14 Ibidem, s. 214

15 J. Bobrzyński, Znaczenie Zjazdu w Dzikowie, „Dzień Polski” 1927, nr 231 z 20 listopada 1927, s. 1.

16 Ibidem.

17 Ibidem. 
Również „Czas” z 25 września 1927 roku, artykułem zatytułowanym Plotki i prawda o Dzikowie odpierał ataki prasowe prawicowych i lewicowych organów publicystycznych. Najgłośniej wypowiadała się Narodowa Demokracja. W „Głosie Narodu" można było wyczytać następujące opinie: Na zjeździe utworzono wspólny front od zwiq̨zku ziemian do zwiq̨zku strzeleckiego... Celem jego jest rozbicie jedynego „narodowego" stronnictwa i zaprowadzenie rządów masonów, żydów i komunistów ${ }^{18}$. Ponadto, celem nie miało być zjednoczenie ugrupowań zachowawczych - to tylko sztuczka mająca na celu zwabienie i oszukanie ziemian, wahających się, komu udzielić poparcia. „Czas” zwracał uwagę, że wiele artykułów pisanych przez sprzyjających endekom redaktorów, pełnych było inwektyw, plotek, wypowiadanych stylem grubiańskim, ordynarnym ${ }^{19}$. Odpowiedź „Głosu Narodu” była natychmiastowa. Redaktor Jan Matysiak w artykule zatytułowanym Dzikowska Góra Pokusy próbował zbagatelizować - jak twierdził krakowski „Czas” - niepokój wywołany Zjazdem Dzikowskim. Stwierdził, że opinia ta wypływa z megalomanii konserwatystów. Zainteresowanie spowodowane jest przede wszystkim udziałem w zjedzie przedstawicieli rządu. Ich wizyta, wcześniej w Nieświeżu, następnie zaś w Dzikowie sugeruje początek współdziałania konserwatystów i rządu. Konsolidacja ugrupowań konserwatywnych to sprawa drugoplanowa, tym bardziej, że przy obecnej konstytucji i ordynacji wyborczej konserwatyści nie mogą odgrywać istotnej roli politycznej. Socjaliści dążenia konserwatystów lekceważą, zaś ludowcy z „Piasta”, mogą być im nawet wdzięczni, bowiem Dzików zapewne ożywi niezadowolenie i niechęć chłopów do ziemian. „Piast”, zwalczany przez radyklanych chłopów za sojusz z obszarnikami (pakt lanckoroński), jest świadkiem podobnego zdaniem publicysty kontrowersyjnego sojuszu. I jeszcze „ukłon” w stronę Stronnictwa Chrześcijańsko-Narodowego (pamiętać należy, że jego członkowie nieustannie balansowali na granicy poparcia dla Narodowej Demokracji i konserwatystów) - autor zwraca uwagę na rozsądną politykę, która pozwoliła zasilić szeregi Stronnictwa ziemianami i inteligencją, natomiast brak bardziej wymiernych efektów działalności „zrzuca na barki” jego przywódców. Jan Matysiak odpierał zarzuty o inwektywy w ordynarnym i grubiańskim stylu, sugerując, że to „Czas” posiadał monopol na posługiwanie się kłamstwem i oszczerstwami. Dezawuował działalność krakowskiego ośrodka konserwatywnego ironizując, że utworzenie jednego ugrupowania konserwatywnego, może przynieść tylko dobre skutki, bowiem obecnie, rozsianie „brużdżących konserwatystów" w wielu partiach i stronnictwach pozwalało na wywieranie przez nich nacisku na Sejm. Na zakończenie wyraźnie zarzucał zachowawcom nadmierne pragnienie władzy. Ostrzegając, że poszukiwanie stronników w zbyt odległych ideowo ugrupowaniach może doprowadzić do zatraty ich tożsamości, ostrzegał, by pewnego dnia ich choragiew nie zalśniła swą dumna białościq w samym środku czerwonych sztandarów ${ }^{20}$.

Echa zjazdu brzmiały w prasie endeckiej jeszcze w kolejnych miesiącach. Artykuły, które ukazały się w „Głosie Narodu” 6 i 7 października 1927 roku, miały już zupełnie inny ton, pozbawiony ironii. W artykule Przygotowanie wyborów Jan Matysiak mówił o tajnym obradowaniu w Dzikowie, sprzysiężonych, o spisku i intrydze, jakie stosuje sanacja w celu zdobycia poparcia w przyszłych wyborach, taki Dzików na chłopskq skalę urządził poseł piastowy Szmigiel w Rzeszowie. Oczywiście zaproszeni piastowcy, nie

18 Plotki i prawda o Dzikowie, „Czas” 1927, nr 219 z 25 listopada 1927, s. 1.

19 Ibidem.

20 J. Matysiak, Dzikowska Góra Pokusy, „Głos Narodu” 1927, nr 261 z 26 listopada 1927, s. 1. 
jedli dziczyzny i nie pili dzikowskich win, ale radzili nad tem samym, co ziemianie u hr. Tarnowskiego: jak zarzucić program i przystąpić do spółki z innymi ugrupowaniami sanacyjnymi ${ }^{21}$. Tym razem ostrze krytyki skierowano w ewentualny sojusz ze „Stronnictwem Chłopskim"; przypominając wydarzenia z 1907 roku $^{22}$, redaktor dążył do zdyskredytowania pozytywnych skutków ewentualnego porozumienia.

W lżejszym tonie wypowiedziała się „Gazeta Narodowa”. Mówiąc o błędach, jakie popełniali dotychczas konserwatyści, piętnując ich bierność przede wszystkim w kwestiach rozwiązywania problemów społecznych, a zwłaszcza dotyczących kondycji polskiego chłopa, autor konstatował: nasi konserwatyści mogą wiele zrobić, jeżeli zapamiętaja słowa śp. Włodzimierza Tetmajera, że droga do wolności i Wielkiej Polski prowadzi przez wieś23. Wzywał też zachowawców do aktywności w zwalczaniu analfabetyzmu, rozwoju zasad moralnych, duchowych i katolickich wśród najniższej polskiej warstwy społecznej, twierdząc, że takie działanie zapewni im poparcie i popularność: Zjazd w Dzikowie świadczy o tem, że nasze zachowawcze czynniki zaczynaja się ruszać i zastanawiać nad tem, co robić maja i jak robić mają ${ }^{24}$.

Wyraźny niepokój związany ze Zjazdem w Dzikowie wyrazili w „Woli Ludu” członkowie PSL „Piast”: ...obecnie za rządów pomajowych, magnateria polska organizuje się do czynnej walki z ludem i demokracją. Sposobi się do samodzielnej akcji wyborczej przy pomocy czynników panoszącej się sanacji... To już zakrawa na zuchwalstwo magnackie - niebywałe, niespotykane dotychczas ${ }^{25}$.

Odczuwalne poruszenie wśród endeków budziły rozpowszechniane informacje dotyczące obecności w Dzikowie przedstawicieli mniejszości żydowskiej. Wprawdzie poseł Kirschbraun zaprzeczył, jakoby przedstawiciele ortodoksów mieli brać udział w obradach w Dzikowie, ale przyznał, że reprezentanci „Agudy” prowadza rokowania z konserwatystami ${ }^{26}$. Niemniej jednak „ziarno niepewności” co do wspólnych posunięć politycznych zostało zasiane na tyle głęboko, że budziło obawy. Tym bardziej, że na łamach „Nowego Dziennika”, reprezentującego polskojęzyczną prasę żydowską, już 26 września 1927 roku pojawiło się stwierdzenie, że spotkanie wymierzone było w endecję $e^{27}$ - Biedni endecy! - dwukrotnie powtarzał autor, czym podkreślał coraz większe osamotnienie ugrupowania na scenie politycznej, następnie konstatował, uczestnicy zjazdu dążyli nie tylko do konsolidacji ugrupowań konserwatywnych, ale też chcieli odciągnąć od endecji Stronnictwo Narodowo-Chrześcijańskie. Wymienione sygnały prasowe stanowiły istotną dla konserwatystów wskazówkę, że podążają we właściwym kierunku, gdyż budując wspólny, umiarkowany front polityczny, mogą stanowić ważną w przyszłym Sejmie siłę polityczną ${ }^{28}$.

Najwięcej krytycznych uwag, wręcz prześmiewczych ocen spotkania pojawiło się w prasie socjalistycznej. Prym w tych opiniach wiódł „Głos Robotnika”: Magnaci pol-

21 J. Matysiak, Przygotowanie wyborów, „Głos Narodu” 1927, nr 271 z 6 października 1927, s. 1.

22 O czem piszq inni? Z dziejów „galicyjskich wyborców”, „Głos Narodu” 1927, nr 263 z 28 września 1927, s. 2.

${ }^{23}$ J. Kozicki, Pierwsze jaskółki z obozu konserwatystów, „Gazeta Narodowa” 1927, nr 35, s. 1.

24 Ibidem, s. 2.

25 Plotki i prawda o Dzikowie..., op. cit.

26 Rokowania konserwatystów z żydami, „Ortodoksy paktują z purycami”, „Głos Narodu” 1927, nr 272 z 7 października 1927, s. 2.

27 W kalejdoskopie prasy, „Nowy Dziennik” 1927, nr 256, s. 5.

28 Plotki i prawda o Dzikowie..., op. cit. 
scy organizują się do walki z Ludem polskim, z demokracja, ze zdobyczami społecznymi robotnika, z reformq rolna, która ma ich olbrzymich majątków ziemskich pozbawić ${ }^{29}$. Autor był przekonany, że z Dzikowa nie wyjdą żadne nowe idee, że jest to miejsce, z którego wieje grobowa stęchliznq ${ }^{30}$. W podobnym kpiącym tonie brzmiały słowa w „Życiu Robotniczym”: czy wszyscy legioniści poprą to kumanie się p. Sławka z konserwq polskq - wątpimy bardzo ${ }^{31}$. Autor twierdził, że najważniejszym jednak celem spotkania była kwestia przyszłych wyborów do Sejmu. Cytując fragmenty z warszawskiej „Rzeczpospolitej”, zwracał uwagę na krążące pogłoski, iż powstał projekt bloku wyborczego obejmującego stronnictwa sanacyjne, ortodoksów żydowskich, ukraińskie UNDO, białoruskich narodowców oraz polskie ugrupowania konserwatywne ${ }^{32}$. Temu miała służyć wizyta Sławka. Zdaniem autora, obrona demokracji parlamentarnej przez endecję paradoksalnie przyczyni się do likwidacji polskiego narodowego kapitalizmu ${ }^{33}$.

Zamykając ten przegląd prasy, należy zaznaczyć, że zrozumienia wydarzeń dzikowskich nie ułatwiali sami konserwatyści, którzy i tym razem nie mówili jednym głosem. 30 września 1927 roku ukazał się w wileńskim „Słowie” artykuł Cata-Mackiewicza, który bagatelizował Zjazd Dzikowski. Porównując go z manifestacją Piłsudskiego w Nieświeżu, Mackiewicz twierdził, iż Dzików był jedynie próbą zjednoczenia kierunków konserwatywnych i próbą sprecyzowania stosunków między zachowawcami - obie te próby żadnych ostatecznych rezultatów nie dały ${ }^{34}$. Wydarzenie to, stało się jednak dla niego okazją do wygłoszenia pewnych refleksji politycznych pod adresem niektórych uczestników oraz wypowiedzi zamieszczanych w organach prasowych SChN. Znany z kąśliwych wypowiedzi konserwatysta poddał krytyce wypowiedź wojewody lwowskiego Dunina-Borkowskiego dla „Epoki”35, wojewoda wysunq̨ł jako przykład możliwości wyborczych kombinację list, na pierwszych miejscach byłaby lewica polska, na drugich Ukraińcy, a na trzecich konserwatyści ${ }^{36}$. Mackiewicz uważa, że taka kombinacja jest niedopuszczalna, krytykuje także wojewodę za brak profesjonalizmu politycznego, żaden bowiem polityk nie ujawnia strategii wyborczej na kilka miesięcy przed kampanią. Do Zjazdu Dzikowskiego ustosunkowali się również konserwatyści zrzeszeni w SChN. „Dziennik Poznański” zamieścił wywiad z prezesem Tadeuszem Szułdrzyńskim, jego słowa: Zjazd miał na celu szczerq i gruntownq wymianę zdań między ludźmi służącymi jednej idei społecznej i politycznej, [...] wytworzył atmosferę ale nie dokonał konkretnych posunięć organizacyjnych; strona organizacyjna opracowywana jest przez istniejącq Komisję Porozumiewawcza, [...]. Rozmowa z płk. Sławkiem pozwoliła nam... zdać sobie sprawę z bieżącej sytuacji państwa i z przeświadczenia panującego $w$ kołach zachowawczych o potrzebie czynnego udziału w życiu politycznym pod własnym sztandarem, przestrzegając bezwzględnie zasad zawartych $w$ programie konserwatyzmu, ${ }^{37}$ wskazują, że krok w kierunku konsoli-

29 Żubry polskie radza, „Głos Robotnika” 1927, nr 230, s. 3.

30 Ibidem.

31 Nowy Nieśwież, „Życie Robotnicze” 1927, nr 38, s. 4.

32 W kalejdoskopie prasy, „Nowy Dziennik” 1927, nr 256, s. 5.

33 Ibidem.

34 S. Cat-Mackiewicz, O konsolidację ziemiaństwa, „Słowo”1927, nr 223 z 30 września 1927, s. 1.

35 [k.w.], „Tajemnice Dzikowa”. P. Wojewoda Dunin-Borkowski o zjeździe ziemiańskim (wywiad specjalny „Epoki”), „Epoka” 1927, nr 266, s. 3

36 S. Cat-Mackiewicz, O konsolidację..., op. cit.

37 Znacznie Zjazdu w Dzikowie, „Dziennik Poznański” 1927, nr 221 z 27 września 1927, s. 2. 
dacji ugrupowań konserwatywnych został co prawda uczyniony, ale porozumienie co do ustępstw wobec rządu jest dalekie. Nieobecny na Zjeździe, niepochwalający udziału w nim Szułdrzyńskiego i Żółtowskiego, Stanisław Stroński na łamach „Warszawianki” ostro atakował wojewodę Dunina-Borkowskiego za wyżej cytowaną wypowiedź dotyczącą wyborów: $p$. Wojewoda Borkowski czuje się w prawie przemawiania imieniem całego ziemiaństwa, a także imieniem stronnictw, np. Stronnictwa Chrześc.-Narod., [...] lecz może przecież p. Wojewoda Borkowski zrozumie, że w Dzikowie był zupełnie samotnym i odosobnionym odyńcem, tak $w$ oświadczeniach imieniem ziemiaństwa jest nawet nie drażniąco, lecz po prostu zabawnie naiwnym samozwańcem ${ }^{38}$.

Przykłady te pokazują złożoność ówczesnej sceny politycznej, trudno wyraźnie oddzielić, usystematyzować stanowiska poszczególnych ugrupowań. Każde z nich kładło nacisk na inny aspekt wynikający ze spotkania w Dzikowie. Szereg jednak przytoczonych opinii pozwala wyciągnąć wnioski o istotnym znaczeniu tego wydarzenia dla ówczesnej polityki wewnętrznej Polski. Co więcej, stał się zjazd swoistym kijem włożonym w mrowisko partii politycznych II RP oraz inicjatywą, która dawała szansę na wejście konserwatystów na scenę polityczną jako ważnego gracza w rozgrywkach o wpływy na decyzje władz. Zastanawia fakt, że prasa konserwatywna dość opieszale zareagowała na spotkanie w Dzikowie. Bowiem dopiero echa zjazdu pobrzmiewające w politycznej prasie mobilizowały jej publicystów do zajęcia stanowiska wobec zdarzenia. Co więcej, prowokacyjne artykuły domagały się wręcz wyjaśnień co do postanowień podjętych w Dzikowie. Najczęściej artykuły te były polemikami, dywagacjami, odpieraniem ataków, opartych na domysłach. Dla konserwatystów zjazd w Dzikowie był przede wszystkim próbą zjednoczenia ruchu, poszukiwaniem wspólnej drogi politycznej i prawdopodobnie nie zdawali sobie sprawy, że wywoła takie zaniepokojenie wśród różnych opcji politycznych. Nie ulega jednak wątpliwości, że szczególnie w tym momencie konserwatyści w życiu politycznym stawali się cennymi partnerami dla Piłsudskiego i groźnymi konkurentami dla innych, przede wszystkim endecji. ${ }^{39}$ Analizując echa zjazdu, należy postawić jeszcze jedno pytanie: jakich informacji dostarczyło spotkanie w Dzikowie samemu Piłsudskiemu? Po przewrocie majowym największą trudność stanowiło dla niego przekonanie do swoich poczynań politycznych konserwatystów z Małopolski Zachodniej, czyli SPN oraz działaczy z Wielkopolski i Pomorza skupionych w strukturach SChN. Wizyta w Nieświeżu była nieoficjalnym, ale wyraźnym sygnałem, spełnieniem obietnic o udziale zachowawców w rządzie oraz dalszych planach współdziałania. Wizyta zaufanego człowieka Marszałka w Dzikowie, gnieździe arystokratycznego, zasłużonego dla Polski rodu z jednej strony, domu przywódcy krakowskich konserwatystów hr. Zdzisława Tarnowskiego z drugiej, była nie tylko otwartą deklaracją, ale też prawdopodobnie sprawdzianem: na jakim etapie konsolidacji znajduje się ruch zachowawczy oraz na jakie poparcie z jego strony w zbliżających się wyborach może liczyć Piłsudski. Wynik był widoczny, opór środowiska krakowskiego był zdecydowanie mniejszy niż rozdartych wewnętrznie konserwatystów w SChN.

Ostatecznie konserwatyści udzielili poparcia obozowi rządzącemu, zatem Piłsudski osiągnął zamierzony cel. Weszli w skład BBWR (chociaż był to trudny, obfitujący w nie-

38 S. Stroński, Odyniec w Dzikowie, „Warszawianka” 1927, nr 267 z 29 września 1927, s. 1.

39 W. Władyka, O konserwatystach raz jeszcze ( $w$ związku z artykułem dyskusyjnym Szymona Rudnickiego pt. „Konserwatyści po przewrocie majowym”) „Przegląd Historyczny” 1979, t. 70, z 1, s. 346. 
jeden konflikt związek). Lata 1928-1930 należy uznać za apogeum wpływów konserwatystów na politykę polską. Wzięli na siebie ciężar prac nad projektem nowej konstytucji, aktywnie uczestniczyli w pracach Sejmu i Senatu, ingerowali w pracę naczelnych organów państwa, swe postulaty przedstawiali bezpośrednio Marszałkowi i jego otoczeniu ${ }^{40}$.

Kolejne lata, do wybuchu II wojny światowej, niejednokrotnie stawiały konserwatystów w trudnych sytuacjach wyboru: idealizm konserwatywny czy prgamatyzm polityczny? Nie zajęli jednolitego, zdecydowanego stanowiska. Stąd też zapewne tak wiele pytań w stosunku do ich działalności. Wśród zawirowań politycznych tego okresu nie można odmówić im jednak dbałości o interes narodowy Drugiej Rzeczypospolitej.

\section{Bibliografia}

Bobrzyński J., Znaczenie Zjazdu w Dzikowie, „Dzień Polski” 1927, nr 231 z 20 listopada 1927.

Chłopceki T., Koncepcje elitaryzmu w myśli Walerego Sławka, „Prace z Myśli PolitycznoPrawnej oraz Prawa Publicznego", Wrocław 2012.

[k.w.], „Tajemnice Dzikowa”. P. Wojewoda Dunin-Borkowski o zjeździe ziemiańskim (wywiad specjalny „Epoki”), „Epoka” 1927, nr 266.

Kozicki J., Pierwsze jaskółki z obozu konserwatystów, „Gazeta Narodowa” 1927, nr 35. Kulesza W.T., Konserwatyści $w$ obozie sanacyjnym w latach 1926-1935: spór o konserwatywnq interpretację ideologii obozu rządzącego, „Przegląd Historyczny” 1982, t. 73, nr 3-4.

Cat-Mackiewicz S., O konsolidację ziemiaństwa, „Słowo”1927, nr 223 z 30 września 1927. Matysiak J., Dzikowska Góra Pokusy, „Głos Narodu” 1927, nr 261 z 26 listopada 1927. Matysiak J., Przygotowanie wyborów, „Głos Narodu” 1927, nr 271 z 6 października 1927. Nowy Nieśwież, „Życie Robotnicze” 1927, nr 38.

O czem piszą inni? Z dziejów „galicyjskich wyborców”, „Głos Narodu” 1927, nr 263 z 28 września 1927.

Protokół konferencji grup konserwatywnych z udziałem przedstawicieli marszałka Piłsudskiego w Dzikowie w dniach 14-16 września 1927 r., „Najnowsze Dzieje Polski" 1959.

Plotki i prawda o Dzikowie, „Czas” 1927, nr 219 z 25 listopada 1927.

Rokowania konserwatystów z żydami. „Ortodoksy paktują z purycami”, „Głos Narodu” 1927, nr 272 z 7 października 1927.

Stroński S., Odyniec w Dzikowie, „Warszawianka” 1927, nr 267 z 29 września 1927.

Władyka W., O konserwatystach raz jeszcze (w związku z artykułem dyskusyjnym Szymona Rudnickiego pt. „Konserwatyści po przewrocie majowym”), „Przegląd Historyczny" 1979, t. 70, z. 1.

W kalejdoskopie prasy, „Nowy Dziennik” 1927, nr 256.

Zjazd arystokracji w Dzikowie. Obecność adiutanta marszałka Piłsudskiego i referat ppł. Sławka, „Goniec Częstochowski” 1927, nr 216.

Znaczenie Zjazdu w Dzikowie, „Dziennik Poznański” 1927, nr 221 z 27 września 1927. Żubry polskie radza, , „Głos Robotnika” 1927, nr 230.

40 W. T. Kulesza, Konserwatyści w obozie sanacyjnym..., s. 232. 


\section{Abstract}

\section{Congress in Dzikow in 1927}

The Tarnowski family is one of the oldest and most important landed gentry families of the Second Polish Republic. In the years 1918-1939 they experienced phenomena and changes that affected them in their entirety. The last representatives of the family, Jan Zdzislaw and his son Artur, actively participated in political and social life, both locally and nationally. The first of them was, among others, a senator and a member of parliament of the Second Polish Republic. The two were also leaders of the conservative movement, which took various organizational forms at that time. The climax of the political significance of the Tarnowskis was the famous congress of the conservatives of Lesser Poland and their meeting with Pilsudski's aide, Col. Walery Slawek, in their family home in 1927. Realizing their mission, Tarnowski family had to, on the one hand, embed it in the family's tradition and the legacy of its great representatives, and on the other, in the dynamically changing social and political processes of the 1930s. Faithful to the will of their ancestors and the principles of conservatism, they became more and more anachronistic in a world where the rules were determined by totalitarian ideologies. World War II brought the destruction of the hitherto known world, as well as the end of the Polish gentry.

\section{Key words:}

Tarnowscy, Dzikow, Second Polish Republic, landed gentry, conservatism 